\title{
Providing the Opportunity to Learn: Unpacking the Role of Mindsets and Leadership in Broadening Participation in STEM at HBCUs
}

\author{
Afiya Fredericks ${ }^{1, *}$, Kimarie Engerman ${ }^{2}$, Camille McKayle $^{2}$ \\ ${ }^{1}$ Department of Psychology, University of the District of Columbia, Washington, USA \\ ${ }^{2}$ Center for the Advancement of STEM Leadership, University of the Virgin Islands, Virgin Islands, USA \\ Email address: \\ Afiya.fredericks@udc.edu (A. Fredericks),kengerm@uvi.edu (K. Engerman),cmckayl@uvi.edu (C. McKayle) \\ ${ }^{*}$ Corresponding author \\ To cite this article: \\ Afiya Fredericks, Kimarie Engerman, Camille McKayle. Providing the Opportunity to Learn: Unpacking the Role of Mindsets and \\ Leadership in Broadening Participation in STEM at HBCUs. American Journal of Applied Psychology. Vol. 10, No. 5, 2021 , pp. 110-119. \\ doi: 10.11648/j.ajap.20211005.12
}

Received: September 11, 2021; Accepted: October 5, 2021; Published: October 12, 2021

\begin{abstract}
Current racial disparities in STEM degree attainment threaten America's ability to be globally competitive. As the need for a more diverse STEM workforce persists, faculty leadership at many Historically Black Universities and Colleges (HBCUs) continue to support, nurture and prepare the next generation of diverse scientists to meet the demands of the 21 st century. However, messages of Black student intellectual inferiority are salient in society, perpetuated by widespread emphasis on the achievement gap and low representation in STEM. Believing that intelligence can be developed through effective effort, resources and support—-growth mindset—has been found to support positive student outcomes and to mitigate the negative effects of stereotypes leading to increased achievement, particularly for Black students. To date, mindsets have not been examined through the lens of Critical Race Theory (CRT) and the four frames of academic leadership. Therefore, this qualitative study examines the experiences of 13 students and 17 faculty members at 4 HBCUs and their perspectives on their STEM programs. The analysis of focus group data suggests that student fixed mindsets may deter students from persisting as STEM majors while faculty growth mindset and support, which fall within the human resources frame of leadership, can help to mitigate those effects. Implications for HBCU leaders are discussed.
\end{abstract}

Keywords: Mindsets, Higher Education Leadership, HBCU, Broadening Participation in STEM

\section{Introduction}

\subsection{Lack of Diversity in STEM}

Preparing and producing a diverse science, technology, engineering and mathematics (STEM) workforce is a critical component in United States' global competitiveness and future national security. However, there are many challenges (e.g., stereotypes, fixed mindsets) that stifle our ability to equitably educate and employ Americans in STEM fields [1, 2]. Historically Black Colleges and Universities (HBCUs) have helped the US compensate for the educational disparities in STEM [3,4] This is demonstrated by their history of successfully recruiting, retaining, and graduating significant numbers of students who enrolled in college while underprepared in mathematics and science or are from racial/ethnic groups that are underrepresented in STEM. We theorize that the success of HBCUs on this front is partially due to their ability to create more growth mindset (intelligence is malleable) -oriented environments for students that counter the fixed mindset (intelligence is innate) messages, abound in STEM.

With professors having significant levels of direct contact with students, their leadership is crucial to supporting the cultivation of adaptive environments where students can thrive. Recent studies on mindsets in higher education have explored the mindset of professors and revealed that they have the potential to positively impact the achievement and motivation of STEM students, and more so for STEM students from underrepresented groups $[2,5]$. This highlights 
the importance of exploring effective academic faculty leadership styles and how different styles may support growth mindset learning-oriented environments. Yet, to date, "mindset" research has not been explored within the context of the four frames of academic leadership and has lacked the robust inclusion of HBCUs. Using a critical race theory (CRT) lens, this qualitative study addresses the gap in mindset research by exploring the experiences of faculty and students at four HBCUs to determine the presence of "mindset" messages in relation to STEM participation.

\subsection{Critical Race Theory}

More generally, American beliefs about intelligence being a fixed, inherent trait, historically have had detrimental effects on many, especially those from marginalized groups [6]. These beliefs influenced public policy, sparking a range of movements including eugenics and educational sorting [6]. The eugenics movement, developed by Sir Francis Galton, posited that individuals who possess 'superior genes' should reproduce, whereas those who possess 'inferior genes' should not. Similarly, education sorting aimed to test children for the purpose of determining who were intellectually superior and inferior, so that resources could be allotted appropriately to support those 'superior' children [7]. Aligned with the largely accepted rhetoric of that time, African American, Latinx and other marginalized groups were overly identified as genetically and intellectually inferior. This which had a significant impact on the questions that researchers of that time asked, the interpretation of their findings and the policies written and enforced that disproportionately affect underrepresented groups negatively.

The current study is guided by Critical Race Theory (CRT) [8-11] a theoretical framework grounded in the belief that there is great value in the voices of those who have been oppressed. Critical Race Theory, "dares to treat race as central to the law and policy of the United States" [12] and posits that the educational inequalities that are present in America are due to the presence of systemic and institutional racism, often muted and pushed aside $[10,13]$. CRT is built on six themes [11] two of which are most salient to the current study. Those themes are:

1. the recognition of the historical context and role of racism in racial advantage and disadvantage seen today;

2. the value placed on the stories and voices of people of the oppressed.

This framework emphasizes the need for the voice of the marginalized and oppressed to be heard in order to better understand their realities through their lens and unique set of experiences, constructing social reality [9-11]. As such, HBCUs present a unique opportunity to qualitatively explore the experiences of faculty and students, as they enroll and prepare a significant percent of students who experience intersecting systems of oppression.

\subsection{HBCUs and Broadening Participation}

HBCUs are well prepared and positioned to address some of the educational inequities that exist in the current US System [4, 14] Black students who attend HBCUs are more likely to major in STEM than those who attend Predominantly White Institutions (PWIs) [15]. About 30\% of Black students who earned their PhDs in STEM in 2010, earned their undergraduate degree from an HBCU. Upton and Tanenbaum [15] attribute HBCUs' high rates of in-educating Black, female and first-generation PhDs, to these institutions' focus on student support and their ability to socially and academically integrate students into STEM fields.

When Black people were refused admittance and access to institutions of higher education, HBCUs were founded to provide an opportunity to educational advancement that they would not have had otherwise. HBCUs were founded around the time of the Civil War until about the 1960s, specifically to educate Black people; when institutions of higher learning at the time, denied them an education [3, 16]. The first HBCU, Cheyney University of Pennsylvania was founded in 1837. However, most HBCUs were founded after the Civil War, during the first part of the 1860s [16]. It was only until the 1960s (approximately 60 years ago) that other institutions became viable options for many Black people, in part, due the Civil Rights movement [3].

Although HBCUs were initially established to serve Black students, its service has since extended to those from other marginalized groups (e.g., women, the poor, people with disabilities) $[3-4,16]$. HBCUs have increased their number of Latinx students and Asian Americans served in the last few decades [17]. They have a higher enrollment of female undergraduate students than the national average [17] and have increasingly embraced and provided support for the LGBT community, through LGBT student organizations [3].

The graduation rates at HBCUs are relatively low compared to PWIs; ; however, context helps to paint a clearer picture of strength and resilience of HBCUs' students. The majority of students that HBCUs serve are also firstgeneration college students and Pell Grant-eligible, and these students are less likely to complete their degrees regardless of the institution [18]. HBCUs have higher acceptance rates than PWIs; and many of their students have lower levels of preparation, for higher education than those enrolled at PWIs [3]. When comparing data of HBCUs to PWIs within the same states, HBCUs, enroll approximately $60.0 \%$ more minorities, students with lower SAT scores (188 - 245 SAT points lower), with more Pell Grant recipients (14.9 - 42.3 percentage points more); however, 6-year graduation rates are lower by only $14.1 \%-22.1 \%$ [19]. The data demonstrate that today, similarly to the time of their inception, HBCUs continue to provide opportunities for all students, regardless of their level of academic preparation. Furthermore, HBCUs are often the best and most affordable option for those who do not come from affluent backgrounds [16].

Although there are few HBCUs in America, compared to PWIs, these institutions hold the potential to significantly mitigate the current STEM diversity crisis. Today there are approximately $105 \mathrm{HBCUs}$ in the US, including the District of Columbia and the United States Virgin Islands [17]. Although 
HBCUs only make up about $3 \%$ of the US higher education institutions, they educate, support and produce a significant number of America's top Black students in STEM [4, 15].

\subsection{Four Academic Leadership Frames}

The approach taken by academic leaders (e.g., Deans, Department Chairs, Professors) in higher education can create environments that either support or hinder student success. In the current study, academic leadership is examined through the lens of the framework developed by Bolman, Deal, and Gallos [20, 21]. This paper applies the framework to identify academic leadership behaviors that lead to broadening participation in STEM. The framework consists of four frames: (a) structural, (b) human resources, (c) political, and (d) symbolic. Clark and Lindahl [22] examined the academic leadership of department chairs and found human resources to be the preferred orientation. This was followed by structural and then symbolic. The least utilized frame was political. An overview of the four frames is provided below.

In the structural frame, academic leaders view the institution as a factory. The focus of leadership is on ensuring that clarity of roles, rules, procedures, and lines of authority exist. A clear structure is evident in all aspects of the institution. This includes the management of time and identification of priorities.

Within the human resource frame academic leaders view the institution as an extended family, maintain a focus on productive workplace, and provide opportunities and resources to aid in advancement of those within the system. Relationships are maintained and open communication occurs. The leader is viewed as a coach or servant.

The political frame differs in that academic leaders have a political orientation. They are focused on allies and coalitionbuilding. These leaders engage in a large amount of bargaining and negotiating.

Symbolic is the fourth frame. Academic leaders with this orientation focus on purpose, culture, and rituals. Significant time and energy are dedicated to fostering a connection to the institution. For this reason, symbolic leaders consider it important to create experiences, typically through rituals, that will create the connection.

According to Bolman and Deal [20], leadership is not limited to one frame. Based on a particular situation, one frame might be more appropriate to use than another frame. Therefore, the frames could be combined at times for a multiframe approach to leadership.

\subsection{Mindsets and Broadening Participation}

Mindsets refer to belief systems that individuals hold about the nature of our intelligence [23]. A fixed mindset is a belief that intelligence is a fixed trait--something one was either born with or not. A growth mindset is the belief that one's intelligence is malleable and can be developed over time with effort. These mindsets have been found to have different motivational patterns $[24,25]$. For example, holding a fixed mindset is negatively associated with challenge seeking behavior, performance goals, and positive effort beliefs. Also, a fixed mindset leads to one attributing failures to a lack of ability. Conversely, a growth mindset has been found to be positively associated with challenge seeking, learning goals, and positive effort beliefs. Additionally, a growth mindset leads to one attributing failure to a lack of effort and effective strategies.

The mindsets individuals hold significantly impact their motivational patterns and ultimately, their academic achievement [23, 24, 26 - 28]. Research has shown significant achievement gains from students exposed to growth mindset interventions. These gains tend to be steeper for Black students and other students from marginalized and underrepresented groups [24, 26, 29]. Moreover, mindset beliefs that professors hold affect their classroom practices and the achievement of their students [2]. Research conducted by Canning and colleagues [2], utilizing data from a population of all students $(\mathrm{N}=15,466)$ enrolled in courses taught by STEM professors at an institution, found that students with professors who believed intelligence to be fixed received lower grade point averages (GPAs) compared to students in STEM courses with professors who held a growth mindset. The relationship between professors' mindset beliefs and student GPAs was stronger for Black, Latinx and Native American students. In this study, in cases where faculty members endorsed a growth mindset, the performance gap in courses between students from underrepresented minority groups in STEM and those from non-underrepresented minority groups, decreased significantly (nearly by half). Findings from this study demonstrate that professors' mindset beliefs have a stronger impact on student achievement than factors like professors' race, age and gender. The results of this study suggest that the beliefs that faculty hold regarding the nature of intelligence may be an important factor in influencing student's decision to pursue post baccalaureate degrees in STEM. Thus, the academic leadership that faculty provide can prove significant in efforts to increase STEM diversity.

\section{Method}

\subsection{Procedure}

The Center for the Advancement of STEM Leadership (CASL), conducted qualitative analysis of focus groups data as part of research funded by the National Science Foundation (NSF). Four focus groups were conducted at HBCUs and included faculty and students. The focus groups discussed a range of questions on participants' perceptions of: (a) their STEM programs, (b) the role that leadership play in broadening participation in their STEM programs, (c) the challenges and success for STEM at their institution, and (d) what they believed could help to broaden participation in STEM at their university.

Researchers obtained Institutional Review Board (IRB) approval prior to the implementation of the study.-Members 
of the CASL research team facilitated the in person focus groups. The lead researcher provided a brief overview of the study's purpose. Due to having students and professors, some of which were from different departments, the researchers consistently encouraged all participants to share after each question was posed. The four main questions that guided each focus group discussion were as follows:

1. What are your impressions of your institution's STEM offerings?

2. How does the leadership of the university help, if at all, to broaden participation in the STEM programs?

3. What are the challenges and successes for STEM here?

4. What else do you think would help to broaden STEM participation at this university?

5. Each focus group was recorded and audio files were uploaded to a secure database. A transcription company was contracted to transcribe the recordings and a member of the research team reviewed the transcription to de-identify the files.

\subsection{Participants}

Both STEM professors $(N=17)$ and STEM students $(N=13)$ at four CASL Affiliate Institutions participated in the focus groups (see Table 1). A greater proportion of professors than students participated in the focus groups due to the limitation of using snowball sampling. Participants were recruited by the CASL Liaison at the institution. The participants in the study were made aware that their participation in this study was completely voluntary and that at any time they could withdraw or not answer a particular question. All participants submitted consent forms.

Table 1. University Demographic Information.

\begin{tabular}{|c|c|c|c|c|}
\hline Demographic Information & Institution 1 & Institution 2 & Institution 3 & Institution 4 \\
\hline Sector & Public & Private $^{1}$ & Public & Public \\
\hline Undergraduate Enrollment & 9,000 & 1,000 & 2,000 & 1,000 \\
\hline Average High School GPA among Freshman & 2.48 & 2.78 & 2.62 & 2.60 \\
\hline$\%$ Underrepresented Minority Students & $85.8 \%$ & $91.0 \%$ & $81.2 \%$ & $82.4 \%$ \\
\hline$\%$ Black Students & $82.1 \%$ & $90.4 \%$ & $78.8 \%$ & $79.3 \%$ \\
\hline \% Pell Recipients Among Freshman & $64.2 \%$ & $81.0 \%$ & $67.1 \%$ & $87.1 \%$ \\
\hline$\%$ STEM Degrees Awarded to Underrepresented Minorities & $72.2 \%$ & $85.7 \%$ & $74.2 \%$ & $57.1 \%$ \\
\hline
\end{tabular}

Note. The Education Trust, College Results Online, 2017. ${ }^{1}$ Not for profit.

\subsection{Data Analysis}

Focus group transcripts were analyzed utilizing methods recommended by Strauss and Corbin [30]. Focus group transcripts were analyzed utilizing open coding, leading to the development of broad categories and themes. There were three main phases that guided the analysis process.

Phase one included the individual analysis where researchers first familiarized themselves with one of four focus group transcripts, selected at random. The researchers read the transcripts without coding. Following this, researchers individually read through the transcript, engaging in open-coding [30] where an exhaustive list of themes were developed. For the final step in phase one, a collaborative analysis was conducted. Utilizing the themes that emerged from individual analysis, researchers met to share, consolidate and define those themes.

Phase two began with more individual analyses of all focus group transcripts, utilizing the coding scheme that was developed in phase one to code appropriate portions of text. Next, utilizing individual codes, researchers came together, using the consensus method to contend with any discrepancies in coding across researchers. The final coding after a consensus was reached was recorded using MAXQDA Software. ${ }^{1}$

Phase three involved reviewing the themes through the lens of the four frames of academic leadership which are structural, human resources, political, and symbolic. Bolman

$1 \mathrm{https}: / /$ www.maxqda.com/products/maxqda-standard and Deal [20] recommended using a multi-frame approach when appropriate. Therefore, the themes were segmented into the four academic frames, and combination of frames when needed.

\section{Results}

The thematic analysis resulted in twenty-eight codes including, faculty support, financial resources, minority status and academic support. However, the present study focused on unpacking one code, 'mindset', that emerged from all focus groups. Analysis of the qualitative data resulted in four themes that emerging for within the code 'mindset':: (a) students' fixed mindsets about STEM; $;$ (b) students' perceptions of professors' mindsets; (c) professors' growth mindsets; $;$ and, (d) cultivating a growth mindset learning environment. The next sections discuss each theme that emerged.

\subsection{Students' Fixed Mindsets About STEM}

Many underrepresented students enter higher education with limited exposure to and preparation in STEM [3, 4]. This suggests that the country is failing to educate, most starkly African American students, in a way that prepares them for higher education STEM courses as they navigate through the K-12 to college pipeline. Added to this, the pervasive stereotypes about marginalized groups and students' experiences in STEM courses, students can develop counterintuitive narratives about who can and cannot succeed 
in STEM, which in turn can limit their STEM interests and persistence [32]. Focus group transcripts revealed that this counterintuitive narrative was present. Students acknowledged the presence of beliefs of STEM courses being perceived as 'hard' and thus only available for a certain group of students (i.e., 'smart') to excel in. Student A shared their experience as a freshman mentor and described how freshmen perception of STEM as 'hard' can lower participation in the field. Student A said:

I'm a freshman mentor for the incoming freshmen. [...] $\mathrm{A}$ lot of them will say like, STEM, that's so hard. Why would I take that?"You know. I'll take-- I'll just stick with my art major." You know, [inaudible] something that's easier because they don't want to put in the work. So I feel like the students kind of have a lot to do with the, um, you know, participation as far as their motivation.

Expressing more perceptions of student fixed mindsets about STEM, Student B said:

[...] a lot of people say they don't go into science because it's [...] like super hard. [They tell me,] 'You're super smart.' I'm not super smart. I [am] just-- discipline[d]. So you have to teach them, like, how to discipline themselves in order to study, to be able to go into the medical field or the science field in order to make it...

Student B described many of their peers' fixed mindsets about STEM, and the recognition of the importance of a counter growth mindset response.; This highlights the value of student effort over ability beliefs, an important contributor to success in STEM. Student B also helps to demonstrate the support that peers can provide to one another, as models and mentors. The perception of STEM as challenging deters students from pursuing those majors. There is also an assumption that STEM subjects are reserved for 'smart people' and if students hold a fixed mindset regarding their intellectual capabilities, this will limit them from pursuing STEM as a major. Murphy and Dweck [31] refer to a 'culture of genius', which is pervasive in the STEM fields. These preconceived notions about STEM are a major obstacle for many students.

However, students also described how important academic support, a sense of belonging and a growth mindset is in STEM persistence beyond the first year. Student C said:

I think that [in] the introductory classes [...], mentoring and the advisement that you have is very important. It's very crucial because I think that your first year is, for some people, their 'make or break' year. So if you don't do well, and if you don't feel supported, if you don't feel like you belong or you're capable of succeeding, then it causes a lot of self-doubt, and I think [...] at that point is when a lot of people will either choose to stay in it and stick through it, or they choose to say that, you know, this is not for me.

Student $\mathrm{C}$ highlighted the importance of the introductory courses as a STEM student and the factors that can deter or support successful completion to a STEM degree. Factors that may hinder participation in STEM are mentioned by Student $\mathrm{C}$, that were frequent across all 4 focus groups including experiences of failure, faculty and academic support, a sense of belonging and mindset. For students who do not believe in their ability to succeed, who hold more of a fixed mindset, those challenges deter them from pursuing careers in STEM fields. This aligns with Blackwell and colleagues [24] who posit that the experience of challenge that we typically see in transitions, like the one from elementary to middle school, is often necessary to see differences in the academic trajectories of those who hold a growth versus a fixed mindset.

\subsection{Student Perceptions of Professors'Mindsets}

Results from the focus groups suggest that one powerful factor that can support students as they navigate these challenges, is the support that professors provide. Professors holding a growth mindset about the nature of their students' intelligence and ability to succeed, can provide the necessary support for students to consider the STEM field as a viable option and persist despite the challenges that arise [2, 33]. Student D shared,

But Dr. [X], uh, told me I could do it, and I've been doing it very well. And I didn't, I didn't even know I liked chemistry that much [laughter], until I got in it and started doing it and getting As in classes that people are extremely afraid of.

The professors' belief in Student D's ability to succeed and their direct communication of it, led the student to apply themselves more and actively work towards success. Student D expressed not knowing that they liked chemistry, until working through challenges and succeeding. This speaks directly to the value of mastery experiences. According to Bandura [34], mastery experiences are the most powerful source of self-efficacy (the belief in your ability to accomplish a particular task). This is where students work hard at a task over time and with effort, achieve. Mastery experiences are also related to one of the motivational constructs associated with student growth mindset, positive effort beliefs [24]. The aforementioned quote reflects the benefit of professors directly communicating their belief in students' potential to achieve, coupled with master experiences, leading to student motivation and success.

Throughout the focus groups, student participants made mention of professors' high expectations for them and their belief in students' unlimited potential. Students expressed that this increased their motivation and their belief in their own abilities, which provided support, leading them to excel in courses that initially, they were not sure that they could. Another student expressed these sentiments as they shared, "it doesn't matter what level you learn at, or where you're at, [our professors] expect you to get that because they know that you can." Regardless of where students were, it was expressed that a huge factor that supported STEM participation and success was knowing that professors believed in their ability to grow and succeed. As such, when students perceive that high expectations are held for them, they are empowered to rise to meet them.

Students shared the academic value of professors directly 
communicating that they believed in their potential to succeed. However, students also perceived professors' growth mindsets through their recommendations of students for opportunities. Student E shared,

[...] I feel like if my professor recommends an internship to me and, you know, asks me to apply, that means you've seen potential in me. [...] it makes me feel better as a, you know, a student, because I'm like, Okay, you've seen potential in me, let me live up to [it]. [...] it's like a great feeling to know that the STEM department believes in you because, you know, you sometimes don't get that support, you know, from other people or your family. And to know that your professors or mentors or anybody believes in you, it just really helps throughout your, you know, college experience.

Students being recommended for opportunities from their professors, (e.g., internships, scholarships and research opportunities) can communicate to students a belief in their ability and potential, which in turn can motivate students to succeed and live up to the high expectations that are held for them. Even in the absence of support from other sources, such as family, students perceiving professors' belief in their potential can serve as a great motivator.

\subsection{Professors' Growth Mindset}

The analysis revealed professors' expression of their beliefs about the unlimited potential of their students (growth mindset) and how they communicate those beliefs to students through multiple modes. These modes include opportunities that they share with students, the high expectations that they communicate directly to students and by taking time to explicitly identify student growth and progress over time, even when students themselves are not conscious that growth and progress are occurring. Communicating the view of students' potential to succeed in STEM, Professor A shares:

Now, the blessing is that there are a lot of diamonds in the rough. They have mad potentials, STEM potentials that have never been tapped. So it's a great opportunity to teach them. [I] firmly believe that every student is gonna [sic] learn. Not in the same way, not on the same day. Okay. Every student can learn.

This statement demonstrates that Professor A believes in the potential of students to learn and the recognition that the learning process will look different for each student. The professor also described teaching students with great potential as an opportunity. This description expresses teaching as more than a 'job' or 'task', it is communicated more as a privilege. This also speaks to the passion that the professor has for the work that they do. Similarly, Professor B expressed that:

Uh, to me every student actually, they have talent. Okay? They have potential, but you need to enhance that potential. It's like driving, you teach somebody to drive something.

Okay? Uh, everybody can read a book, how to drive a car, but by reading the book, actually, they will not give you a license to drive. So this is the way we do it here. You have to put the student behind the wheel to drive the car. Before, they used to say, Well, this type of research is too much for our students. [...] Once they start really taking classes in the field, this will be too late for a student, really, to do meaningful research.

This is why we start from freshmen. Freshmen [...] allowed to do research will make them involved with more studies. Because [of these early experiences], they [will] know the basics.

Professor B echoed the sentiments of many professors in the focus groups. There is a belief that regardless of where students currently are, they have the potential and the ability to succeed in STEM. Thus, professors support students from their freshman year to participate in research, so that they can build the skills that they need to succeed and be competitive in STEM. Again, this demonstrates what students express. Being provided with opportunities is one way professors can communicate high expectations to students. Adding to the expression of growth mindset beliefs in students, Professor $\mathrm{C}$ shared: "scores of the students would rise to the level of teacher expectations." This statement directly speaks to the importance of the beliefs that professors hold. If there is a belief of students' unlimited potential to achieve and these beliefs are communicated through high expectations, with support, students have the capacity to meet those expectations.

Focus groups participants also expressed that many students enrolled are coming from secondary schools where they were not adequately prepared. Current statistics support that schools where there are larger numbers of underrepresented and marginalized groups of students tend to not offer opportunities for them to take higher level mathematics and science courses [35]. According to the Civil Rights Data Collection (CRDC), conducted by the ED [35], high schools where more than $75 \%$ of students enrolled are Black and Latinx, offer advanced mathematics, Calculus, and Physics at lower rates, compared to the national population. Thus schools with high populations of underrepresented students often lack access for students to take rigorous math and science courses, allowing them to be competitive and prepared for STEM majors and courses [36, 37]. Professor C shared these sentiments, "Sometimes we just have kids in high school who don't have the background that they need. [...] but it's not that they don't have the capabilities.". The acknowledgement of the academic realities of many students that are enrolled in STEM majors at HBCUs are a clear challenge for these institutions. However, a professor's being awareness that "students lack opportunities to succeed" is not synonymous with "students not having the ability to succeed" is fundamental to supporting STEM success.

\subsection{Cultivating a Growth Mindset-Oriented Learning Environment}

Throughout the focus groups, professors acknowledged many of the financial and academic disadvantages (e.g., low SES, limited upper-level math courses offered at their high school) that students faced as they entered into the learning 
environment. The recognition of challenge and historical context led professors to take more of a strengths-based perspective versus one of deficit. Not having the 'Opportunity to Learn' is a major barrier for many students [1] and this is what many STEM professors are trying to provide at their respective HBCUs, because they believe that students have the potential to thrive, despite the many challenges that they face (e.g., poverty, lack of preparation). In this vein, Professor D shared:

[...] let them know that they can do [it]. And despite the fact that as most of them come from schools where they haven't had the most important thing, I think, is OTL - the Opportunity To Learn. [...] They haven't had the opportunity to learn math in the way they can understand it.

Believing that students need the opportunity to learn, places responsibility on professors and school leaders to provide the resources and support necessary to optimize the learning environment for students to thrive.

In addition to student beliefs and the beliefs that professors hold about the intellectual capabilities and potential of their students to succeed, strategies that help build a growth mindset-oriented environment were shared. Professor D shared: "how do you teach or reach the students, and how do you get them? They need one success, right? They need success to break the point that I' can do this." This statement describes this professor's belief in creating mastery experiences as integral to supporting students. According to Bandura, mastery experiences are the most powerful source of self-efficacy. It can be argued that providing mastery experiences can cultivate a growth mindset-oriented learning environment, where students take on challenges and exert effective effort, believing that their efforts (versus innate ability) will maximize success.

Acknowledging that many students enrolled at HBCUs enter with limited exposure to rigorous STEM curriculum, but believing that students have the potential to be successful utilizing evidence-based practices also emerged as integral to supporting students. In addition, strategies to directly support student learning of STEM content were shared. Professor F expressed:

They haven't had the opportunity to learn the math in the way they can understand it. [Previously, it has been] pretty much, you just sit there quietly and Let me fill your head, and then regurgitate it back to me when we have a test." But, [...] here we have the freedom to teach in ways that research is currently saying [are] best practices.

Professor F not only acknowledged that STEM students often have been lacking the opportunity to learn in ways that are student centered, but emphasized the importance of utilizing evidence-based practices. Although programs do exist to prepare doctoral students to teach (E.g., Preparing Future Faculty Programs) oftentimes, college professors are not trained in pedagogy prior to entering the classroom as professors [38]. However, it is important that professors, particularly those in STEM, not only believe that students can achieve, but also lean on research supported strategies to teach and facilitate learning in the classroom. It is not enough for professors to believe that their students can learn and grow. It is the responsibility of professors to look beyond antiquated methods that may have been used when they were taught and lean on the science of teaching and learning to support their practice.

\subsection{Mindset and Leadership}

The growth mindset exemplified by professors in the study aligned most closely with the human resource academic leadership frame. Professors discussed how they communicated their beliefs about students' unlimited potential to students in multiple forms. Core aspects of the human resource frame are encouragement and communication. As academic leaders in STEM, the professors in this study, served as a coach and emphasized motivating and empowering students. By openly communicating their honest opinions, academic leaders create an environment that allow students to demonstrate their best abilities. This is exemplified in Professor B's statement, "To me every student actually, they have talent. Okay? They have potential, but you need to enhance that potential."

Furthermore, the human resource frame is concerned with nurturing an adequate workforce. As such, the frame also focuses on the development of skills and opportunities for growth and development. Professors in the focus groups talked about providing students with research opportunities to be competitive in STEM fields. At some institutions, opportunities were provided to freshmen.

Moreover, professors acknowledge that students attending their HBCU institutions may be underprepared-in STEM by their secondary schools. Comments on the racial inequities in the educational system reflected components of the structural frame mixed with the political frame. The inequities in the secondary schools could have impacted students' mindset and performance in STEM. The misalignment that existed in the curriculum at secondary schools attended by underrepresented students exemplified the structural frame. Policies, rules, and programs were not created to provide students with a quality education. Also, the political frame was evident by the lack of resources at the secondary schools. The lack of adequate programs in secondary schools placed students at a disadvantage in college. However, the creation of evidence-based practices to support student learning was evidence of the human resource frame overcoming deficits caused by the structural and political frames to prepare students to excel in STEM.

\section{Conclusion}

\subsection{Discussion and Implications}

The purpose of this study was to use a qualitative methodology to explore the experiences of STEM faculty and students at HBCUs to better understand the role that mindsets and academic leadership styles of faculty play in broadening 
STEM. Analysis of focus group data revealed that there is a pervasive belief held by HBCU students that STEM courses are extremely difficult and thus, only the most intellectually adept (i.e., 'smart people'), can succeed and should enter these fields. With this belief, students who hold a fixed mindset about their own intellectual abilities are more likely to disqualify themselves from STEM majors, especially once presented with challenges or even worset, failures. With students' fixed beliefs about STEM and their abilities, factors that emerged as potential alleviators were support of student peers in STEM through sharing effective effort strategies that lead to their success, debunking the myth that 'STEM is only for smart people' and STEM professors holding a growth mindset for their students.

Two ways students expressed professors communicating their belief in students' potential to succeed was through direct verbal communication and the opportunities (E.g., internships, research, co-ops) that professors share with students. Professors also directly expressed their belief in student potential, driving their high expectations of students and providing them with opportunities to meet the high expectations. These behaviors aligned with the human resource frame of academic leadership.

Additionally, professors acknowledged the challenges of students being underprepared upon entering undergraduate STEM courses. Professors communicated their belief that students are capable of success, but have simply been lacking the opportunity to learn. This places the onus of providing learning opportunities on professors and university leaders. Strategies that professors utilize that support a growth mindset learning environment were shared. These strategies included providing mastery experiences for students and looking to the extant literature for evidence-based practices to support teaching and learning.

Empirical mindset research has been consistent in showing that holding a growth mindset and being taught by educators who hold a growth mindset and communicate them through feedback and praise, have significant benefits for all students, but more impactfully for those that have been traditionally marginalized [2, 23, 24, 28, 39]. This qualitative study supports and extends prior findings. This research holds significant implications for the impact that faculty, who have direct and consistent contact with students, can have on student participation and success in STEM at HBCUs. Specifically, the beliefs that we hold about students' and their potential, can impact the environments that we create for them, and the beliefs that they internalize for themselves as they pursue a STEM degree.

\subsection{Limitations}

Although focus group moderators made deliberate efforts to include both students and professors in discussions by directing questions at each group when necessary, there was an imbalance in the number of students and professors in each focus group and, potential that neither group felt comfortable providing their open and honest thoughts. Additionally, the study's purpose was not explicitly focused on mindsets. As such, probing to understand the implications of mindset beliefs on student success, classroom experiences and culture did not occur.

\subsection{Increasing Diversity Through Mindsets}

As a matter of national security, America must prepare a competitive (STEM) workforce, but is grappling with a race problem in education while contending with an increasingly diversified citizenry. Despite millions of dollars that have been allotted to support programs and initiatives aimed to address the disparities that exist within the STEM pipeline and workforce $[40,41]$ these disparities still exist. Although there are few HBCUs in America, compared to PWIs, HBCUs demonstrate great promise at continuing to increase the participation of marginalized groups in STEM [4, 14, 15, 18, 42]. They enroll greater numbers of underrepresented students, and support and nurture a larger proportion of students; from marginalized and underrepresented groups; entering the US STEM workforce [3, 4, 17]. The universities in this study created growth mindset-oriented learning environments that counter the fixed mindset messages pervasive in American media, school systems, research and policy.

Despite the appearance of the government investing considerable amounts of financial capital towards diversifying the STEM workforce, "In the academic year of 2016-2017, three TWIs [Traditionally White Institutions] received more federal revenue from grants and contracts than did all HBCUs [Historically Black Colleges and Universities] combined" [4]. In fact, according to 2018 United States Department of Education (ED) data, "on average, each HBCU received \$15 million from the federal government for grants and contracts annually, whereas the total annual average for all institutions of higher education was \$21.1 million." [4]. Despite not having a "Research Very High" 1 (R1) Carnegie classification, many HBCUs are among the top producers of Black college graduates who later become science and engineering doctorate degree holders (NSF, 2019) --arguably as successful as Ivy Leagues and more successful than colleges with larger numbers of Black undergraduates enrolled (e.g., other colleges with R1 designations). In the face of this level of STEM success, this supports the need for continued and increase funding for HBCUs, to support STEM education and research.

Through decades of research, growth mindset has been shown to play an integral role in increasing academic achievement for students in higher education [2, 5, 26, 27] by increasing motivational constructs like challenge seeking behavior, learning goals and positive effort beliefs. HBCUs may be pioneers in countering preexisting fixed mindset messages and promoting growth mindsets about Black intelligence and Black students' STEM capabilities. Increasing more equitable investments for HBCUs, while aiming to better understand and document the practices their academic leaders at all levels (i.e., professors and administrators) engage in to cultivate a growth mindsetoriented learning environment, can help create models for all 
institutions as they support STEM degree attainment of marginalized and underrepresented minorities.

If educational leaders applying human-centered approaches-can develop and strengthen a growth mindset in students, educators, and administrators--creating a growth mindset-oriented learning environment--the potential is maximized to create a more equitable future. A future where all people regardless of race, ethnicity, nationality, or poverty level are supported and empowered to unleash their unlimited, unknowable potential on the world.

\section{Acknowledgements}

This work was supported by the National Science Foundation through the Center for the Advancement of STEM Leadership (CASL) under NSF Grant No. 1818424, 1818425, 1818447, and 1818459. Any opinions, findings, and conclusions or recommendations expressed in this report are those of the authors and do not necessarily reflect the views of the National Science Foundation. The authors thank Dr. Jennifer Burrell Hudson for useful discussions and research consulting services.

\section{References}

[1] Boykin, A. W., \& Noguera, P. (2011). Creating the opportunity to learn: Moving from research to practice to close the achivement gap. ASCD.

[2] Canning, E. A., Muenks, K., Green, D. J., \& Murphy, M. C. (2019). STEM faculty who believe ability is fixed have larger racial achievement gaps and inspire less student motivation in their classes. Science Advances, 5 (2). https://doi.org/10.1126/sciadv.aau4734

[3] Gasman, M. (2013). The changing face of historically black colleges and universities. Penngse Center for MSI, 1-18.

[4] Toldson, I. A. (2019). Cultivating STEM Talent at Minority Serving Institutions: Challenges and Opportunities to Broaden Participation in STEM at Historically Black Colleges and Universities [Chapter]. ACS Symposium Series, 1328, 1-9. https://doi.org/10.1021/bk-2019-1328.ch001

[5] Muenks, K., Canning, E. A., LaCosse, J., Green, D. J., Zirkel, S., Garcia, J. A., \& Murphy, M. C. (2020). Does My Professor Think My Ability Can Change? Students' Perceptions of Their STEM Professors' Mindset Beliefs Predict Their Psychological Vulnerability, Engagement, and Performance in Class. Journal of Experimental Psychology: General. https://doi.org/10.1037/xge0000763

[6] Saphier, J. (2016). High expectations teaching: How we persuade students to believe and act on "smart is something you can get.". Thousand Oaks, CA: Corwin.

[7] Terman, L. M. (1916). The measurement of intelligence: An explanation of and a complete guide for the use of the Stanford revision and extension of the Binet-Simon Intelligence Scale. New York, NY: Houghton Mifflin.

[8] Bell, D. (1987). And we are not saved: the elusive quest for racial justice. New York, Basic Books.
[9] Delgado, R., \& Stefancic, J. (2012). Critical race theory: An introduction (2nd ed.). New York: NYU Press.

[10] Ladson-Billings, G. \& Tate, W. (1995) Toward a critical race theory of education, Teachers College Record, 97 (1), 47-68.

[11] Matsuda, M., Lawrence, C., Delgado, R. \& Crenshaw, K. (Eds) (1993) Words that wound: critical race theory, assaultive speech and the first amendment (Boulder, CO, Westview Press).

[12] Harris, A. (2012). Foreword. In R. Delgado \& J. Stafancic, Critical race theory: An introduction (pp. xvii -xxi). (2nd ed.). New York: NYU Press.

[13] Dixson, A. D., \& Rousseau, C. K. (2005). And we are still not saved: Critical race theory in education ten years later. Race Ethnicity and Education, 8 (1), 7-27. https://doi.org/10.1080/1361332052000340971

[14] Gasman, M. (2007). "Swept under the Rug? A Historiography of Gender and Black Colleges." American Educational Research Journal. 44 (4): 760-805.

[15] Upton, R., \& Tanenbaum, C. (2014). The Role of Historically Black Colleges and Universities as Pathway Providers: Institutional Pathways to the STEM PhD Among Black Students. Broadening Partcipation in STEM Graduate Education, 2010 (September), 1-12. http://www.nsf.gov/statistics/srvydoctorates/.

[16] Eno, V. (2019). Historically Black Colleges and Universities (HBCUs) and Education of Marginalized Populations. 60-76. https://doi.org/10.4018/978-1-5225-7787-4.ch003

[17] National Center for Education Statistics, Institute of Education Sciences, U.S. National Science Foundation. (2013). National Center for Science and Engineering Statistics Baccalaureate Origins of U.S.-trained S\&E Doctorate Recipients. Arlington, VA (NSF 13-323).

[18] Gasman, M., \& Samayoa, A. C. (2017). Historically Black colleges and universities: Fostering familial learning environments for student success. Retrieved from https://www.higheredtoday.org/2017/10/04/historically-blackcolleges-universities-fostering-familial-learningenvironments-student-success/. Accessed 9 January 2021.

[19] The Education Trust. (2010) College Results Online. North Carolina \& Mississippi institutional data. The Education Trust. (2017) College Results Online.

[20] Bolman, L., \& Deal, T. (1991). Reframing organizations. San Francisco: Jossey-Bass.

[21] Bolman, L., \& Gallos, J. (2011). Reframing academic leadership. San Francisco: Jossey-Bass.

[22] Clark, S. L., \& Lindahl, R. A. (2014). University Council for Educational Administration.

[23] Dweck, C. S. (2006). Mindset: The new psychology of success. New York: Random House.

[24] Blackwell, L. S., Trzesniewski, K. H., \& Dweck, C. S. (2007). Implicit theories of intelligence predict achievement across an adolescent transition: A longitudinal study and an intervention. Child Development, 78 (1), 246-263. https://doi.org/10.1111/j.1467-8624.2007.00995.x

[25] Dweck, C. S., \& Leggett, E. (1988). A social-cognitive approach to motivation and personality. American Psychological Association, 95, 256-273. 
[26] Aronson, J., Fried, C. B., \& Good, C. (2002). Reducing the effects of stereotype threat on African American college students by shaping theories of intelligence. Journal of Experimental Social Psychology, 38 (2), 113-125. https://doi.org/10.1006/jesp.2001.1491

[27] Good, C., Aronson, J., \& Inzlicht, M. (2003). Improving adolescents' standardized test performance: An intervention to reduce the effects of stereotype threat. Journal of Applied Developmental Psychology, 24 (6), 645-662. https://doi.org/10.1016/j.appdev.2003.09.002

[28] Yeager, D. S., Dahl, R. E., \& Dweck, C. S. (2018). Why interventions to influence adolescent behavior often fail but could succeed. Perspectives on Psychological Science, 13, 101-122.

[29] Paunesku, D., Walton, G. M., Romero, C., Smith, E. N., Yeager, D. S., \& Dweck, C. S. (2015). Mind-Set Interventions Are a Scalable Treatment for Academic Underachievement. Psychological Science, 26 (6), 784-793. https://doi.org/10.1177/0956797615571017

[30] Strauss, A., \& Corbin, J. (1998). Basics of qualitative research: Techniques and procedures for developing grounded theory. Thousand Oaks, CA: Sage.

[31] Murphy, M., \& Dweck, C. S. (2010). A culture of genius: How an organization's lay theory shapes people's cognition, affect and behavior. Personality and Social Psychology Bulletin, 36, 283-296. doi: 10.1177/0146167209347380.

[32] Dai, T., \& Cromley, J. G. (2014). Changes in implicit theories of ability in biology and dropout from STEM majors: A latent growth curve approach. Contemporary Educational Psychology, 39 (3), 233-247. https://doi.org/10.1016/j.cedpsych.2014.06.003

[33] Rattan, A., Good, C., \& Dweck, C. S. (2012). "It's ok - Not everyone can be good at math": Instructors with an entity theory comfort (and demotivate) students. Journal of Experimental Social Psychology, 48 (3), 731-737. https://doi.org/10.1016/j.jesp.2011.12.012

[34] Bandura, A. (Ed.) (1995). Self-efficacy in changing societies. New York: Cambridge University Press.
[35] U.S. Department of Education. (2018). The Integrated Postsecondary Education Data System (IPEDS). National Center for Education Statistics. STEM course taking. April, 112. https://nces.ed.gov/ipeds/

[36] Rodriguez, A. (2018). Inequity by Design? Aligning High School Math Offerings and Public Flagship College Entrance Requirements. Journal of Higher Education, 89 (2), 153-183. https://doi.org/10.1080/00221546.2017.1341757

[37] Toldson, I., \& Lewis, C. (2012). Public reciprocity in education for postsecondary success (PREPS) for students of color: The legal justification and a call for action (Editor's commentary). The Journal of Negro Education, 81, 1-9. Retrieved from http://www.jstor.org/stable/10.7709/jnegroeducation.81.1.0001

[38] McGlynn, T. (2020). The Chicago Guide to College Science Teaching. University of Chicago Press.

[39] Yeager, D. S., Walton, G. M., Brady, S. T., Akcinar, E. N., Paunesku, D., Keane, L., Kamentz, D., Ritter, G., Duckworth, A. L., Urstein, R., Gomez, E. M., Markus, H. R., Cohen, G. L., \& Dweck, C. S. (2016). Teaching a lay theory before college narrows achievement gaps at scale. Proceedings of the National Academy of Sciences of the United States of America, 113 (24), E3341-E3348.

[40] American Institutes for Research. (2012). Broadening participation in STEM: A call to action. Washington, DC: Author.

[41] Committee on Equal Opportunities in Science and Engineering. (2019). Committee on Equal Opportunities in Science and Engineering 2017-2018 Biennial Report to Congress: Investigating in Diverse Community Voices. https://www.nsf.gov/od/oia/activities/ceose/reports/CEOSE_R eportToCongress_RP_FVmp_508.Pdf

[42] National Science Foundation. (2019). National Science Board, Higher Education in Science and Engineering. Science and Engineering Indicators 2020. NSB-2019-7. HBCU Enrollment Rates component. Alexandria, VA. 